\section{Yale Center for British Art}

Public Information, Education and Programs, 1080 Chapel Street, PO Box 208280, New Haven, CT 06520-8280, United States of America.

Tel: $\quad$ (1) 2034322850

Email:_bacinfo@yale.edu

Website: www.yale.edu/ycba

Contact: Ms Mary Beth Graham, Acting Programme

Co-ordinator

The Yale Center for British Art houses the most comprehensive collection of English paintings, prints, drawings, rare books and sculpture outside the United Kingdom. Given to Yale University by Paul Mellon, the Center's resources illustrate British life and culture from the 16th century to the present.

\section{Andrew W Mellon Fellowship}

Purpose: To promote the study of British art

Eligibility: Open to foreign students enrolled for a higher degree at a British or other non-American university

Level of Study: Postgraduate

Type: Fellowship

Value: US $\$ 15,000$ plus return airfare from London, health benefits and travel expenses up to US $\$ 1,000$

Length of Study: 1 year

Frequency: Annual

Study Establishment: The Yale Center for British Art

Country of Study: United States of America

Application Procedure: There is no application form. Please submit name, address, telephone number, CV listing professional experience, education and publications, three page outline of research proposal, and two confidential letters of recommendation
No. of awards offered: 2

Closing Date: 15 January

Funding: Private

No. of awards given last year: 1

No. of applicants last year: 2

For further information contact:

Email: bacinfo@minerva.cis.yale.edu

\section{Yale School of Management (SOM)}

135 Prospect Street, Box 208200, New Haven, CT 065208200 , United States of America.

Tel: $\quad$ (1) 2034325932

Email: admissions@admin.som.yale.edu

Contact: MBA Admissions Officer

\section{Arthur Liman Public Interest Law Fellowship}

Purpose: The Arthur Liman Public Interest Law Summer Fellowship Program supports the work of law students, law school graduates, and students from six universities, all of whom work to respond to problems of inequality and to improve access to justice

Eligibility: The Liman Fellowship program supports Harvard College undergraduates who perform domestic summer fellowships in public interest law at a 501(c)(3) nonprofit organization. Students who perform fellowships in the following fields are eligible for consideration: 1. Client-oriented, direct service case work and litigation, both civil and criminal. 2. Enforcement work and other litigation for governmental agencies. 3. Alternative dispute resolution, such as negotiation, mediation, and arbitration. 4. Policy-making legislative and regulatory reform. 5. Policy-oriented class action and impact legislation 
Level of Study: Graduate

Type: Fellowship

Frequency: Annual

Country of Study: Any country

Application Procedure: At the time of application, students need not have identified a specific project. The Liman advisor at Brown will help with placements, including at organizations with Liman Fellows. However, if students are interested in specific substantive areas or projects, they should describe them in their application. The Review Committee will evaluate applications with preference toward applications that: 1. Focus on public service work that has a clear and significant legal flavor. All else being equal, the more fully the summer fellowship engages the legal system, the more favorably the committee will view the application. 2. Demonstrate the applicant has carefully researched the summer fellowship site. 3. Demonstrate the applicant has thoughtfully considered how the summer fellowship would support the applicant's academic and career interests

Closing Date: 11 January

Funding: Private

Contributor: The Liman Summer Fellowships at Brown are funded by the generous support of Arthur Liman's son, the filmmaker Doug Liman and the Liman Foundation

Additional Information: Summer Fellows have worked on issues such as immigrant's rights, worker's rights, prison conditions, educational equity, juvenile justice and marriage equality

\section{For further information contact:}

Email: tlovett@fas.harvard.edu

\section{Yanshan University}

438 Hebei Street West Section, Haigang Qu, Qinhuangdao Shi, Hebei Sheng, China.

Contact: Yanshan University

The Yanshan University is a university in Qinhuangdao, Hebei, China under the provincial government. It has a student population of 39,000 and a staff population of 3,200. It is a national key school and runs state key labs on its campus.

\section{China Scholarship Council Scholarships}

Purpose: The scholarship is awarded only to $\mathrm{PhD}$ candidates Eligibility: For eligibility refer website www.cscscholar ships.net/yanshan-university-csc-scholarships-ranking-agencynumber-and-faculty.html
Value: Registration fee, tuition fee, and accommodation fee for dormitory on campus, monthly allowance: $¥ 1,400$ for 12 months/year, one-off settlement subsidy: $¥ 2,000$

Length of Study: 3 to 4 years

Country of Study: China

Application Procedure: For application procedure, please refer website www.cscscholarships.net/yanshan-universitycsc-scholarships-ranking-agency-number-and-faculty.html

Closing Date: May

\section{For further information contact:}

Email: scholarships@cscscholarship.com

\section{Chinese Government Scholarship Program}

Purpose: Chinese Government Scholarship Program is established by the Ministry of Education of P.R. China in accordance with educational exchange agreements or understandings reached between the Chinese government and the governments of other countries, organizations, education institutions and relevant international organizations to provide both full scholarships and partial scholarships to international students and scholars

Eligibility: For eligibility, please visit website

Type: Scholarship

Value: Master’s degree students and general scholars: $¥ 1,700$; doctoral degree students and senior scholars: $¥ 2,000$. Exempt from registration fee, tuition fee, fee for laboratory experiment, fee for internship, fee for basic learning materials; and accommodation fee for dormitory on campus

Length of Study: 1 to 2 years for both post graduate and doctorate degrees

Country of Study: China

Application Procedure: Please visit website english.ysu. edu.cn/info/2345/1095.htm

Contributor: Yanshan University

Additional Information: The CSC Online Application System for Study in China is available on laihua.csc.edu.cn english.ysu.edu.cn/info/2345/1095.htm

\section{For further information contact:}

Email:zizhu2@csc.edu.cn

\section{Yanshan University Doctoral Scholarships}

Purpose: The aim of the scholarships is to provide financial help to the students who are coming to study in China Eligibility: Non-Chinese citizens are eligible to apply for this scholarship programme

Type: Scholarships 
Value: Registration fee, tuition fee, and accommodation fee for dormitory on campus. Monthly allowance of $¥ 1,400$ for 12 months, one-off settlement subsidy $¥ 2,000$

Country of Study: Any country

Application Procedure: Please visit website www.cscscholar ships.org/yanshan-university-doctoral-scholarships.html

Closing Date: 20 May

Contributor: Yanshan University

Additional Information: Please visit website english.ysu. edu.cn/info/2345/1092.htm www.chinesescholarshipcouncil. com/yanshan-university-doctoral-scholarships.html

For further information contact:

Email: study@ysu.edu.cn

\section{Yanshan University Scholarship Program for International Students}

Purpose: Scholarships are available for pursuing master degree programme

Eligibility: Non-Chinese citizens are eligible to apply. For more details, visit website

Value: First class scholarship covers the following: registration fee, tuition fee, and accommodation fee for dormitory on campus. The second class scholarship covers the following: registration fee and tuition fee

Country of Study: China

Application Procedure: The mode of applying is online. Email application to study@ysu.edu.cn

Closing Date: 20 May

For further information contact:

Email: study@ysu.edu.cn

\section{Yidisher Visnshaftlekher Institut Institute for Jewish Research}

15 West 16th Street, New York, NY 10011-6301, United States of America.

Tel: $\quad$ (1) 2122466080

Email:_pglasser@yivo.cjh.org

Website: www.yivoinstitute.org

Contact: Dr Paul Glasser, Dean, Senior Research

Associate

YIVO Institute for Jewish Research was founded in 1925, in Vilna, Poland as the Yiddish Scientific Institute, the YIVO Institute for Jewish Research is dedicated to the history and culture of Ashkenazi Jewry and to its influence in the Americas.

\section{Abraham and Rachela Melezin Fellowship}

Purpose: To support doctoral and postdoctoral research on Jewish educational networks in Lithuania, with emphasis on pre-war Vilna and the Vilna region

Level of Study: Doctorate, Postdoctorate

Type: Fellowship

Value: US $\$ 1,500$

Length of Study: 1-3 months

Frequency: Annual

Study Establishment: YIVO Library and Archives

Country of Study: United States of America

Application Procedure: Applicants must send a covering letter, curriculum vitae, research proposal and 2 letters of support through regular mail, fax or email

Closing Date: 31 December

Additional Information: A written summary of one's research is required; a public lecture is optional www. petersons.com/scholarship/abraham-and-rachela-melezin-

fellowship-111_153684.aspx

\section{Abram and Fannie Gottlieb Immerman and Abraham Nathan and Bertha Daskal Weinstein Memorial Fellowship}

Purpose: To support travel for $\mathrm{PhD}$ dissertation research in archives and libraries of the Baltic states with preference given to research on the Jews of Courland and Latvia

Eligibility: For those engaged in $\mathrm{PhD}$ dissertation research in archives and libraries of the Baltic states with preference given to research on the Jews of Courland and Latvia

Level of Study: Doctorate, Research

Type: Fellowship

Value: US\$2,000

Frequency: Every 2 years

Application Procedure: Applicants must send a cover letter, curriculum vitae, research proposal and 2 letters of support through regular mail, fax or email. A written summary of one's research is required

Closing Date: 31 December

Funding: Private

Additional Information: www.petersons.com/scholarship/ abram-and-fannie-gottlieb-immerman-and-abraham-nathanand-bertha-daskal-weinstein-memorial-fellowship-111_182 517.aspx

\section{For further information contact:}

YIVO Institute for Jewish Research, 15 West 16 Street, New York, NY 10011, United States of America. 


\section{Aleksander and Alicja Hertz Memorial Fellowship}

Purpose: To encourage research on Jewish-Polish relations and Jewish contributions to Polish literature and culture in the modern period

Level of Study: Doctorate, Postdoctorate

Type: Fellowship

Value: US $\$ 1,500$

Length of Study: $1-3$ months

Frequency: Annual

Country of Study: United States of America

Application Procedure: Applicants must send their curriculum vitae, research proposal and 2 letters of support through regular mail, fax or email. A written summary of one's research is required

Closing Date: 31 December

Additional Information: www.petersons.com/scholarship/ aleksander-and-alicja-hertz-memorial-fellowship-111 153683.aspx

\section{Dina Abramowicz Emerging Scholar Fellowship}

Purpose: To support a significant scholarly publication that may encompass the revision of a doctoral dissertation

Eligibility: Applicants are required to give a public lecture Level of Study: Postdoctorate

Type: Fellowship

Value: US $\$ 3,000$

Length of Study: $1-3$ months

Frequency: Annual

Application Procedure: Applicants must send their curriculum vitae, a research proposal and 2 letters of support through regular mail, fax or email

Closing Date: 31 December

Additional Information: Please check website for more details www.petersons.com/scholarship/dina-abramowiczemerging-scholar-fellowship-111_153681.aspx

\section{Dora and Mayer Tendler Fellowship}

Purpose: To support graduate research in Jewish studies with preference given to research in YIVO collections

Eligibility: Graduate applicants must carry out original research in the field of Jewish studies and give a written summary of the research carried out

Level of Study: Doctorate, Graduate

Type: Fellowship

Value: US $\$ 3,000$

Frequency: Annual

Study Establishment: YIVO collections

Country of Study: United States of America
Application Procedure: Applicants must send a cover letter, curriculum vitae, research proposal and 2 letters of support through regular mail, fax or email

Closing Date: 31 December

Additional Information: A public lecture at the end of the tenure of the Fellowship is optional www.petersons.com/schol arship/dora-and-mayer-tendler-fellowship-111_169669.aspx

\section{For further information contact:}

Email: eportnoy@yivo.cjh.org

\section{Joseph Kremen Memorial Fellowship}

Purpose: To financially assist researchers at the YIVO Archives and Library

Eligibility: A written summary of one's research is required Level of Study: Postgraduate, Research

Type: Fellowship

Value: US $\$ 2,000$

Frequency: Annual

Application Procedure: Applicants must send their curriculum vitae, research proposal and 2 letters of support by regular mail, fax or email

Closing Date: 31 December

Additional Information: www.petersons.com/scholarship/ joseph-kremen-memorial-fellowship-111_175652.aspx

\section{Maria Salit-Gitelson Tell Memorial Fellowship}

Purpose: To support original doctoral or postdoctoral research in the field of Lithuanian Jewish history, the city of Vilnus in particular, at the YIVO Library and Archives

Eligibility: Applicants must carry out original doctoral or postdoctoral research in the field of Lithuanian Jewish history and give a public lecture at the end of the tenure of the Fellowship

Level of Study: Doctorate, Postdoctorate

Type: Fellowship

Value: US $\$ 1,500$

Length of Study: $1-3$ months

Frequency: Annual

Study Establishment: YIVO Library and Archives

Country of Study: United States of America

Application Procedure: Applicants must send a cover letter, curriculum vitae, research proposal and 2 letters of support through regular mail, fax or email

Closing Date: 31 December

Additional Information: www.petersons.com/scholarship/ maria-salit-gitelson-tell-memorial-fellowship-111_153686.aspx 


\section{Natalie and Mendel Racolin Memorial Fellowship}

Purpose: To support original doctoral or postdoctoral research in the field of East European Jewish history at the YIVO Library and Archives

Eligibility: Applicants must carry out original doctoral or postdoctoral research in the field of East European Jewish history and give a public lecture at the end of the tenure of the Fellowship

Level of Study: Doctorate, Postdoctorate

Type: Fellowship

Value: US $\$ 1,500$

Length of Study: $1-3$ months

Frequency: Annual

Study Establishment: YIVO Library and Archives

Country of Study: United States of America

Application Procedure: Applicants must send a cover letter, curriculum vitae, research proposal and 2 letters of support through regular mail, fax or email

Closing Date: 31 December

Additional Information: www.petersons.com/scholarship/ natalie-and-mendel-racolin-memorial-fellowships-111_153685. aspx

\section{Professor Bernard Choseed Memorial Fellowship}

Purpose: To financially support doctoral and postdoctoral students who conduct research

Eligibility: Applicants are required to give a public lecture Level of Study: Doctorate, Postdoctorate

Type: Fellowship

Value: US\$7,500

Length of Study: $1-3$ months

Frequency: Annual

Country of Study: United States of America

Application Procedure: Applicants must submit a curriculum vitae, a research proposal and 2 letters of support through regular mail, fax or email

Closing Date: 31 December

Additional Information: www.petersons.com/scholarship/ professor-bernard-choseed-memorial-fellowship-111_153138. aspx

\section{Rose and Isidore Drench Memorial Fellowship}

Purpose: To encourage research in American Jewish history Eligibility: Applicants are required to give a public lecture Level of Study: Doctorate, Postdoctorate

Type: Fellowship

Value: US\$2,500

Length of Study: 1-3 months
Frequency: Annual

Application Procedure: Applicants must submit their curriculum vitae, a research proposal and 2 letters of support through regular mail, fax or email

Closing Date: 31 December

Additional Information: www.petersons.com/scholarship/ rose-and-isidore-drench-memorial-fellowships-111_151729. aspx

\section{Samuel and Flora Weiss Research Fellowship}

Purpose: To support research on the destruction of Polish Jewry or on Polish-Jewish relations during the Holocaust period

Eligibility: Applicants must carry out original research on the destruction of Polish Jewry or on Polish-Jewish relations during the Holocaust period and give a written summary of the research carried out. The research should result in a scholarly publication

Level of Study: Doctorate

Type: Fellowship

Value: US $\$ 2,500$

Frequency: Annual

Country of Study: Any country

Application Procedure: Applicants must send a cover letter, curriculum vitae, research proposal and 2 letters of support through regular mail, fax or email

Closing Date: 31 December

Additional Information: A public lecture at the end of the tenure of the Fellowship is optional www.petersons.com/ scholarship/samuel-and-flora-weiss-research-fellowship-111_ 175653.aspx

For further information contact:

Tel: (1) 212294613

Email: pglasse@yivo.cjh.org

\section{Vivian Lefsky Hort Memorial Fellowship}

Purpose: To support original doctoral or postdoctoral research in the field of Yiddish literature

Eligibility: Applicants must carry out original doctoral or postdoctoral research in Yiddish literature and give a public lecture at the end of the tenure of the Fellowship

Level of Study: Doctorate, Postdoctorate

Type: Fellowship

Value: US\$2,000

Length of Study: $1-3$ months

Frequency: Annual

Study Establishment: YIVO Library and Archives

Country of Study: United States of America 
Application Procedure: Applicants must send a cover letter, curriculum vitae, research proposal and 2 letters of support through regular mail, fax or email

Closing Date: 31 December

Additional Information: www.petersons.com/scholarship/ vivian-lefsky-hort-memorial-fellowship-111_151730.aspx

\section{Vladimir and Pearl Heifetz Memorial Fellowship in Eastern European Jewish Music}

Purpose: To assist undergraduate, graduate and postgraduate researchers defray expenses connected with research in YIVO's music collection at the YIVO Archives and Library Eligibility: Undergraduate, graduate and postgraduate researchers who will carry on research in YIVO's music collection at the YIVO Archives and Library

Level of Study: Graduate, Postgraduate

Type: Fellowship

Value: US\$1,500

Frequency: Annual

Study Establishment: YIVO's music collection

Country of Study: United States of America

Application Procedure: Applicants must send a cover letter, curriculum vitae, research proposal and 2 letters of support through regular mail, fax or email

Closing Date: 31 December
Funding: Foundation

Additional Information: A written summary of one's research is required; a public lecture is optional gradfund. rutgers.edu/blog/awards/2485/

\section{Workmen's Circle/Dr Emanuel Patt Visiting Professorship}

Purpose: To support postdoctoral research at the YIVO Library and Archives

Level of Study: Postdoctorate

Type: Fellowship

Value: US $\$ 5,000$

Length of Study: 3 months

Frequency: Annual

Study Establishment: YIVO Library and Archives

Country of Study: United States of America

Application Procedure: Applicants must send a covering letter, curriculum vitae, research proposal and 2 letters of support through regular mail, fax or email

Closing Date: 31 December

Additional Information: The visiting faculty member should give a public lecture at the end of the award's tenure www.petersons.com/scholarship/workmens-circledr-emanuelpatt-visiting-professorship-in-eastern-european-jewish-studies111_169668.aspx 